\title{
Postnatal Development of Testis in Gaddi Goat (Capra hircus)
}

\author{
Desarrollo Postnatal del Testículo en la Cabra Gaddi (Capra hircus)
}

\author{
Archana, P.; Katiyar, R. S.; Sharma, D. N.; Farooqui, M. M. \& Ajay Prakash
}

\begin{abstract}
ARCHANA, P.; KATIYAR, R. S.; SHARMA, D. N.; FAROOQUI, M. M. \& PRAKASH, A. Postnatal development of testis in Gaddi goat (Capra hircus). Int. J. Morphol., 32(1):166-176, 2014.

SUMMARY: A study was conducted on the testicles of 30 male Gaddi goats, divided into 3 groups viz; prepubertal ( 0 day to 18 months), pubertal ( $<18$ months to $>5$ yrs) and post- pubertal ( $>5$ yrs) ages. The study revealed that the testis was covered by fibroserous tunica albuginia having outer fibrous layer and inner vascular layer with smooth muscle fibers at birth. The tunica albuginia continuously grew in thickness from prepubertal to postpubertal animals. The septula testis arising from the tunica albuginia, divided the parenchyma in lobules and converged at mediastinum testis. Few differentiated and undifferentiated Leydig cells were present in the intertubular spaces of neonates, which enormously increased in pubertal animals and replaced by fibroblasts in the postpubertal animals. The parenchyma comprised of solid sex cords in new born kids. These were converted into luminated tubules after 6 months of age and had clear cut tubuli contorti and tubuli recti leading to the mediastinum testis. In "0" day old kids, sex cords were filled with undifferentiated small cells located peripherally along the basement membrane and large primordial germ cells located centrally. By six months of age, latter started showing sign of degeneration and thus luminization of tubules started. Spermatogenesis startedin the seminiferous tubules of 12-18 months goat. In pubertal animals all the stages of spermatogenic cells and Sertoli cells were identified in the seminiferous tubules. The population of gonia cells and primary + secondary spermatocytes were $35 \%$ and $30 \%$ respectively. In postpubertal animals gonia cells were reduced to $<30 \%$ and Primary + secondary spermatocytes were $<20 \%$. Many degenerating seminiferous tubules showed hyalinization, fibrosis and giant cells. The stroma and parenchyma ratio which was 35:65 at birth became 30:60 at 6 months, 25:75 at 12 months and 15:85 in pubertal and 20:80 in postpubertal animals. Increased stroma in last phase was associated with replacement of seminiuferous tubules by fibrous elements.
\end{abstract}

KEY WORDS: Testis; histology; Postnatal development; Goat.

\section{INTRODUCTION}

Gaddi gaots are reared by the tribes of Kangra, Kullu, Shimla, Sirmour and Chamba district of Himachal Pradesh. They are the backbone of the economy of the marginal farmers, landless and tribal people of the North Western Himalayan region of India. The time of puberty and maturation plays an important role in the successful reproductive management of the domestic animals. Goats are seasonal breeders and the age of puberty in male differs from breed to breed (Gupta, 1989), which is indicatedby the appearance of spermatozoa in the ejaculated semen. Although, Gaddi goats are one of the most important breed of North Western Himalayan region of country, yet no systemic work has been conducted on the postnatal development of testis. This paper records the sequential account of structural changes in the testis from birth to puberty till senility.

\section{MATERIAL AND METHOD}

Tissue collection. The study was conducted on the testis of 30 male Gaddi goats. The testes were procured from the apparently healthy animals from the municipal slaughter houses of Palampur (H.P). The neonatal specimens were collected from the subjects at the clinics of Veterinary College Palampur. The tissues were classified into three age groups of 10 animals in each viz; prepubertal (1 day old to $<18$ months of age), pubertal (18 months to $<5$ yrs of age) and postpubertal ( $>5 \mathrm{yrs}$ of age) age groups. The age of animals were estimated by the dental formula/teeth eruption.

Histological study. The thin pieces of tissues were collected from the testis and fixed in $10 \%$ neutral buffered formalin. The fixed tissues were processed through the routine alcohol-benzene schedule, infiltrated and embedded in paraffine 
(60-620C). Thin sections $(5 \mu)$ were cut and stained with hematoxylene and eosin for routine fibrocellular architecture, Van Gieson's stain for collagen fibers, Gomori's reticulin method for reticular fiber and Weigert's resorcin Fuchsin and orcein stain for elastic fibers and PAS stain for carbohydrate.

Micrometry and statistical analyses. Micrometric data on various component of testis were collected with the help of precalibrated ocular micrometer on the stained paraffin sections. Percentile ratio between the stroma and parenchyma was calculated by the help of projection drawings on the standard art paper. Differential counting of the various seminiferous germinal epithelial cells was done by the blood cell counter. The data was put to standard statistical analyses.

\section{RESULTS}

\section{Stroma}

Capsule: In one day old kids, the testes were enclosed in a fibro-serous tunica albuginea forming its true capsule (Fig. 1) It was externally lined by flat mesothelium. The fibrous capsule was $116.90 \mu \mathrm{m}$ thick. It had clear cut an outer zone of tunica fibrosa (37.22 $\mu \mathrm{m}$ thick) made up of dense irregularly arranged collagenous fibers and an inner zone of tunica vasculosa (78.99 $\mu \mathrm{m}$ thick) comprising of loose collagenous and reticular fibers (Figs. 2 and 3). In addition, fine elastic fibers were encountered in the walls of capsular blood vessels (Fig. 4).

In pre-pubertal Gaddi goats the tunica albuginea was $416.13 \pm 42.04 \mu \mathrm{m}$. The tunica fibrosa and tunica vasculosa were $234 \pm 26.86 \mu \mathrm{m}$ and $174.89 \pm 12.96 \mu \mathrm{m}$ thick, respectively (Table I). The thickness of the testicular capsule

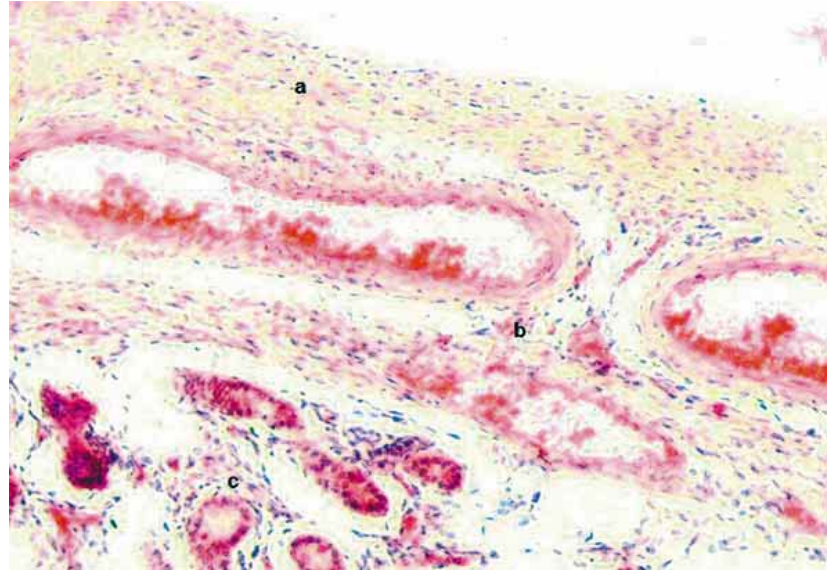

Fig. 1. Photomicrographs of testis of one day old Gaddi kid showing capsule (a) and parenchyma (b). H\&E 100X.

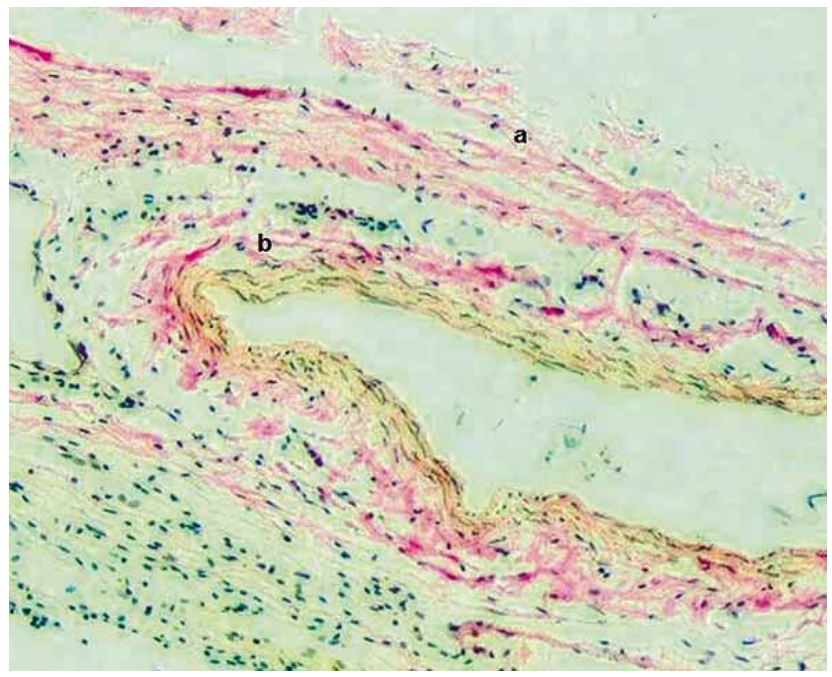

Fig. 2. Photomicrographs of testis of one day old Gaddi kid showing collagen in the fibrosa of tunica albuginea (a) and reduced collagen in the wall of blood vessels of tunica vasculosa (b). Van Gieson's stain 100X.

Table I. Micrometrical parameters (Mean+SE) of the testis in Gaddi goats in various age groups.

\begin{tabular}{clccc}
\hline S. $\mathbf{n}$ & Parameters $(\boldsymbol{\mu m})$ & Pre-p ubertal & Pubertal & Post-pubertal \\
\hline \multirow{2}{*}{1} & Thickness of tunica albuginea & $416.14 \mathrm{a} \pm 42.04$ & $616.42^{\mathrm{b} \pm} 12.09$ & $697.02 \mathrm{c} \pm 9.34$ \\
& Range & $(116-555)$ & $(538.02-658.56)$ & $(616.42-722.20)$ \\
\multirow{2}{*}{2} & Thickness of tunica fibrosa & $234.12 \mathrm{a} \pm 26.86$ & $363.38^{\mathrm{b}} \pm 6.95$ & $404.05 \mathrm{~b} \pm 2.29$ \\
& Range & $(37.28-317.52)$ & $(325.36-394.94)$ & $(391.02-412.58)$ \\
\multirow{2}{*}{3} & Thickness of tunica vasculosa & $174.89 \mathrm{a} \pm 12.96$ & $251.86^{\mathrm{b}} \pm 7.80$ & $304.24 \mathrm{c} \pm 2.40$ \\
& Range & $(78.99-226.38)$ & $(198.94-295.96)$ & $(293.51-315.56$ \\
\multirow{2}{*}{4} & Diameter of seminiferous tubules & $157.58 \mathrm{a} \pm 16.38$ & $202.55^{\mathrm{b}} \pm 4.49$ & $263.52 \mathrm{c} \pm 5.22$ \\
& Range & $(36.32-207.76)$ & $(181.74-226.29)$ & $(241.08-303.8)$ \\
\hline
\end{tabular}

$\mathrm{a}, \mathrm{b}, \mathrm{c}=$ shows the significant difference between the groups. Values of ten observations each of ten animals in each group. 
increased with the advancement of age. At about 12 months of age the tunica albuginea showed three distinct layers viz; outer loose connective tissue layer having collagenous fibers, intermediate vascular layer containing blood vessels and smooth muscle fibers and the third inner layer formed of dense regularly arranged collagenous and reticular fibers.

In pubertal animals, the tunica albuginea resembled to that of the preceding group. It was however significantly thicker as compared to the pre-pubertal group. Its total mean thickness measured $616.42 \mu \mathrm{m}$ with the tunica fibrosa and tunica vasculosa measuring $363.38 \mu \mathrm{m}$ and $251.86 \mu \mathrm{m}$, respectively (Table I). The condensed and mature collagen fibers were distributed in the interlobular connective tissue.

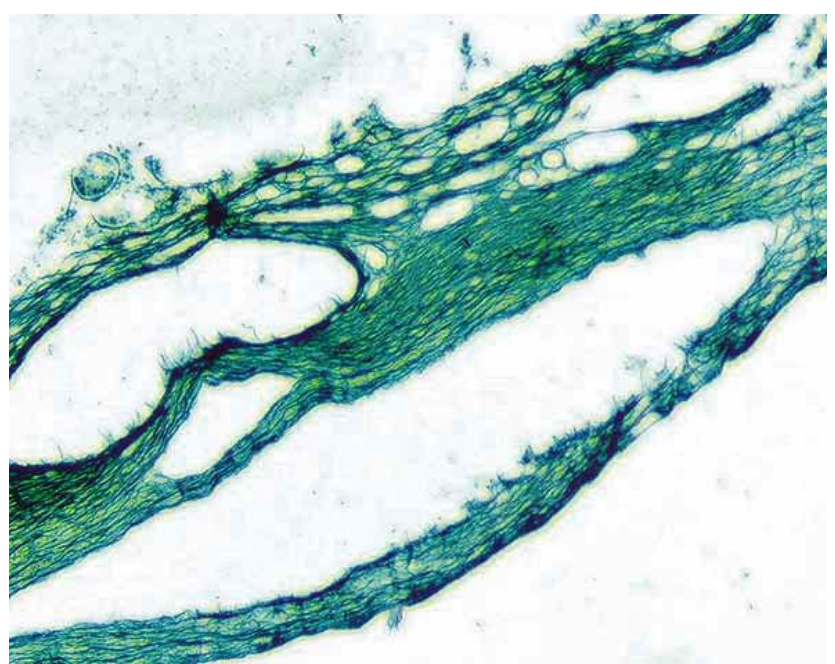

Fig. 3. Photomicrographs of testis of one day old Gaddi kid showing reticular fibers in the capsule of the testis. Gomori's reticulin stain $100 X$.

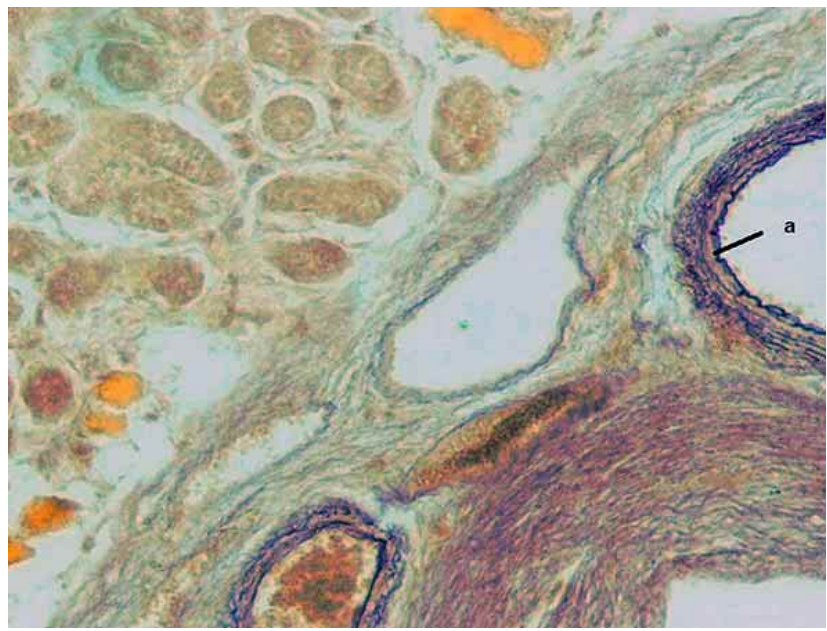

Fig. 4. Photomicrographs of testis of one day old Gaddi kid showing elastic fibers in the tunica vasculosa (a). Weigert's Resorcin fuchsin stain $100 X$.
Fine collagen extended into the intralobular connective tissue. Elastic fibers were seen in the walls of blood vessels of the capsule particularly in the adventitia. Fine elastic fibers were present in the tunica fibrosa and up to some extent also in the deepest layer of tunica albuginea.

In post-pubertal animals, the total thickness of tunica albuginea was $697.02 \mu \mathrm{m}$. The tunica fibrosa and tunica vasculosa were $404.05 \mu \mathrm{m}$ and $304.24 \mu \mathrm{m}$ in thickness, respectively (Table I). The dense collagenous elements increased in the intertubular connective tissue. Reticular and elastic fibers became coarser with the advancement of age.

Septula testis: The septula testis was indistinct in day old kids (Fig. 5). In prepubertal animals, these septae contained fine collagenous and coarse reticular fibers. The thickness of septula testis increased further in pubertal and postpubertal

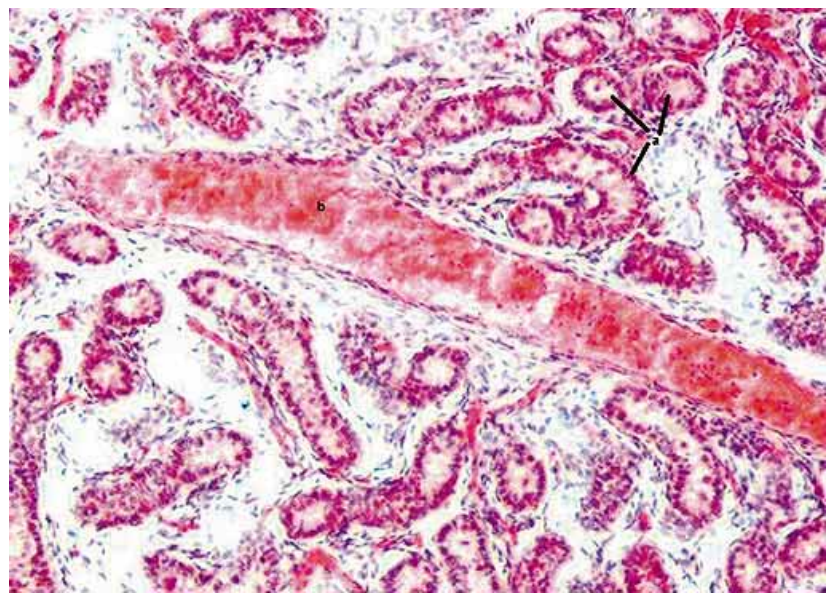

Fig. 5. Photomicrographs of testis of one day old Gaddi kid showing parenchyma of testis showing trabecular blood vessels in the connective tissue septum (a) and sex cords (b). H\&E 100X.

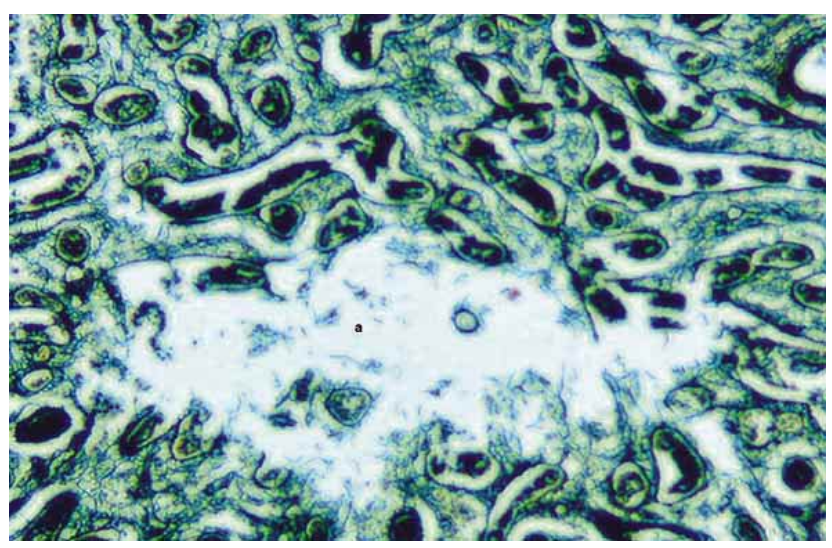

Fig. 6. Photomicrographs of testis of one day old Gaddi kid showing mediastinum testis (a), rich in blood vessels and connective tissue. 2-3 contorti joins to form one tubuli recti (b). Gomori's reticulin stain $100 \mathrm{X}$. 


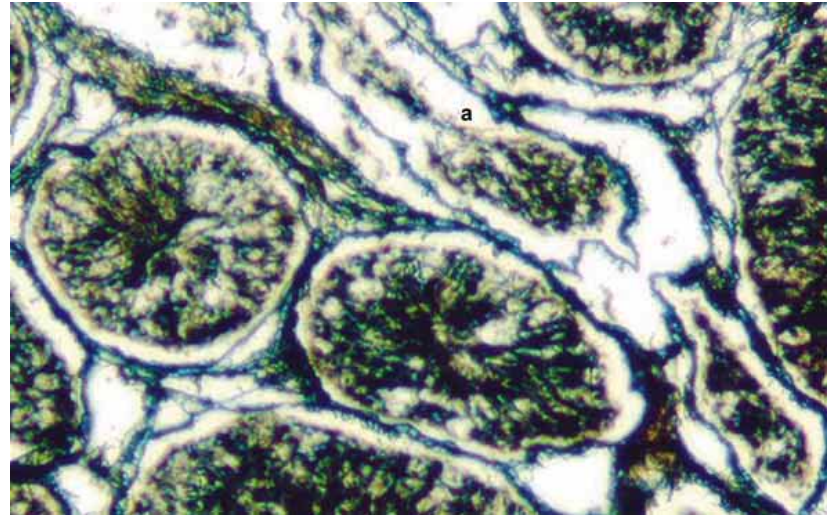

Fig. 7. Photomicrograph of testis of pubertal Gaddi goat showing intraseptal rete testis (a). Gomori's reticulin stain 100X.

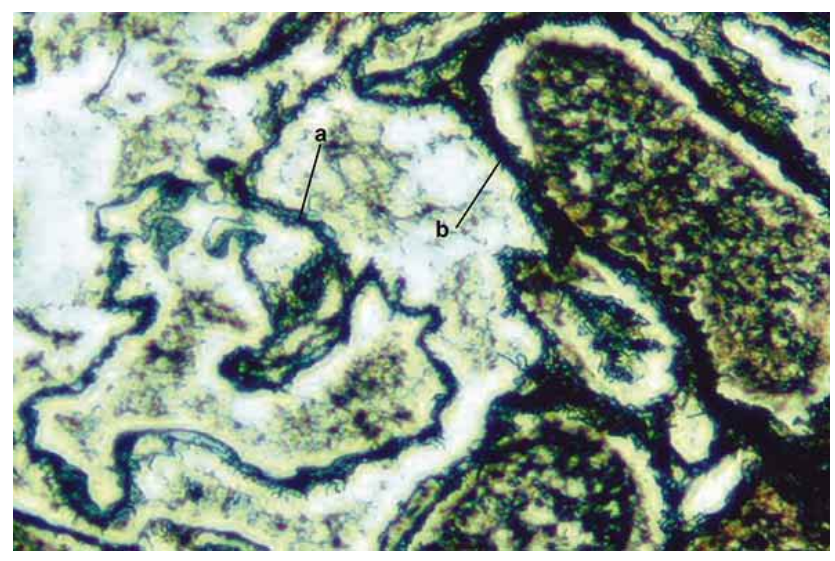

Fig. 8. Photomicrograph of testis of pubertal Gaddi goat showing reticular fibers along the basement membrane of the rete testis (a) and around the tubules (b). Gomori's reticulin stain 100X.

animals with age. It contained fine elastic fibers in addition to the collagenous and reticular fibers. These septae contained small as well as medium sized blood vessels.

Mediastinum testis: In one day old kids, the mediastinum testis was present centrally and consisted of irregularly arranged collagenous fibers with few reticular fibers (Fig. 6). Elastic fibers were found within the walls of peripherally placed blood vessels. The central connective tissue (core) consisted of fibroblasts in various stages of development. A small number of blood vessels were present in the peripheral region of the mediastinum testis.

In pubertal animals, the mediastinum testis comprised of numerous, mostly longitudinally arranged fine elastic fibers in addition to the collagenous and reticular fibers. It had many blood vessels of different sizes (Figs. 7 and 8). In post-pubertal animals, the number of elastic fibers increased and all the connective tissue fibers became coarser. The amount of elastic fibers was increased.

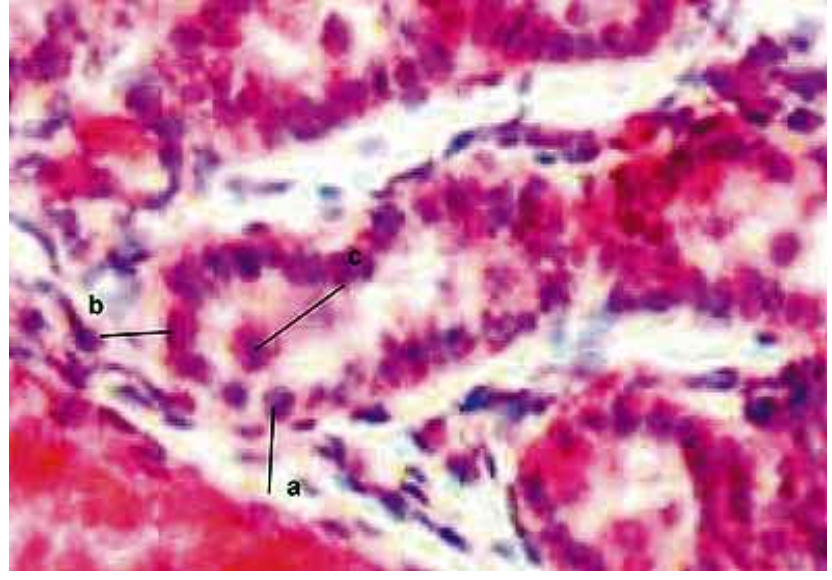

Fig. 9. Photomicrographs of testis of one day old Gaddi kid showing sex cords filled with small indifferent subtype I (a), subtype II (b), large primordial germ cells (c) and interstitial tissues (d). H\&E 200X.

Interstitial tissue: In one day old kids, the interstitial (intertubular/inter-sex cords) tissue was fibro-cellular. It contained fibroblasts, mesenchymal cells, undifferentiated as well as few differentiated Leydig cells (Fig. 9). The mesenchymal cells were irregular in outline with weakly stained eosinophilic cytoplasm and lightly stained vesicular nucleus. The fibroblasts were spindle shaped cells with darkly stained nuclei, which predominated the other cells in number. The undifferentiated Leydig cells were spindle, elongated or ovoid shaped. Their cytoplasm appeared eosinophillic and granular. The nuclei of these cells were rounded or oval, eccentrically placed. They occurred in small groups of 23 in between the fibroblasts. Their nuclear membrane was indistinct. The chromatin material was fine and uniformly distributed. The differentiated Leydig cells were typical ovoid or roughly triangular and sometimes rounded in shape with highly vacuolated eosinophilic cytoplasm. Round or ovoid nuclei of these cells were generally present eccentrically towards the broader end of the cell. The nuclear membrane was distinct and the chromatin was coarse or sometimes dusts like, distributed more towards the nuclear membrane. They occurred singly or in groups.

In pubertal animals, the Leydig cells mostly dominated the other cells types (Fig. 10). They occurred in groups of variable sizes and measured on an average $8.10 \mu \mathrm{m}$ in diameter. Their nuclei measured $4.81 \mu \mathrm{m}$ in diameter. The number and size of Leydig cells further increased in post-pubertal animals as compared to pubertal animals. They measured $9.75-9.95 \mu \mathrm{m}$ in diameter. The nuclear diameter ranged from 5.01 to $5.05 \mu \mathrm{m}$. 


\section{Parenchyma}

Sex cords: The testicular parenchyma in new born kids consisted of solid tubular structures designated as sex cords (Fig. 11). They were separated from each other by means of loose fibro-cellular interstitial tissue. The percent ratio between the glandular parenchyma and connective tissue stroma was 35:65 at this age. The sex cords were nonluminated more straight than coiled structure. They had an average diameter of $36.32 \mu \mathrm{m}$. There was no appreciable difference in the diameter of the sex cords of the peripheral, central and mediastinal locations of the testis. Each sex cord had a basement membrane surrounded by fine collagenous and reticular fibers. A single incomplete layer of fibroblast surrounded the sex cords beyond the fibro-reticular layer. All the sex cords were filled with small indifferent basal cells and large primordial germ cells (PGC) designated as gonocytes (Fig. 9). The small cells were spherical in shape, lay along the periphery and dominated the larger cells in number. Their boundary lines were barely discernible and the cytoplasm was moderately eosinophillic. Based on difference in size and staining intensity of nuclei, these could be further classified into two different sub-types. The subtype I cells had rounded or oval nuclei which laid on the basement membrane. They had single nucleolus which was placed slightly eccentrically. The sub-type II cells were characterized by their elongated shape. They were placed at intervals between the type I cells (Fig. 9). Their chromatin was diffused and did not mask the nucleolus.

The large primordial germ cells (PGC) were spherical in shape and mostly present in the centre of the cord (Fig. 9). But more than often they were also found in between the small cells in some of the sex cords. The cytoplasm was slightly acidophilic and usually vacuolated with distinct cell boundary. These cells $(8.48 \pm 0.25 \mu \mathrm{m}$ in diameter $)$ were characterized by their large spherical nuclei $(6.42 \pm 0.23 \mu \mathrm{m}$ in diameter). Their chromatin material was clumped beneath the nuclear membrane. Typical Sertoli cells and spermatogonia could not be identified in the sex cords of neonatal testis.

With the advancement of age, the size/diameter of the sex cords increased. At 6 months of age, the sex cords constituted about $60 \%$ of total testicular parenchyma. Individual sex cords measured about $141.19 \mu \mathrm{m}$ in diameter. The smaller indifferent cells of both types i.e. sub-type I and sub-type II aligned themselves along the periphery of the sex cords, close to the basement membrane. A few subtype II cells appeared to have elongated and were in the process of differentiation into Sertoli like cells characterized by their vertical orientation and ovoid/elongated nuclei towards the base. The primordial germ cells showed

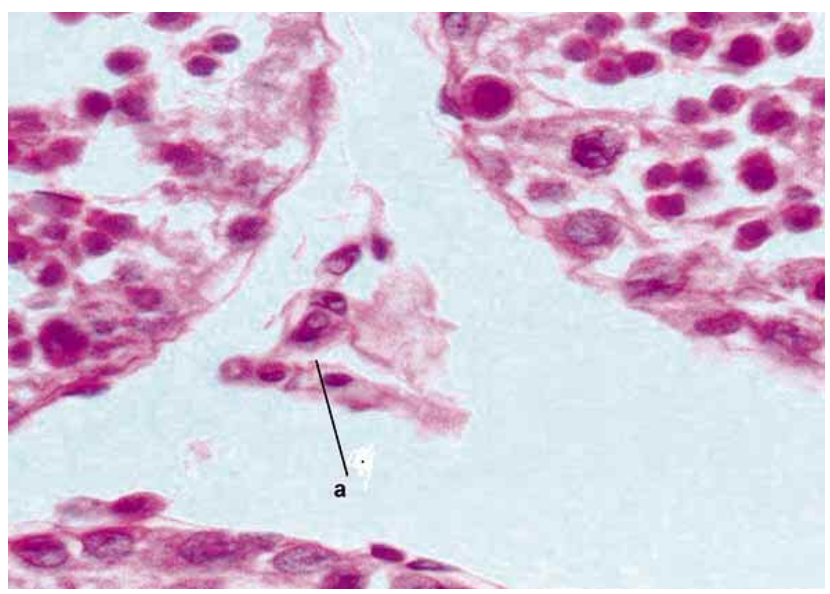

Fig. 10. Photomicrograph of testis of pubertal Gaddi goat showing PAS reaction in the spermatogonia (a), primary spermatocytes (b), secondary spermatocytes (c) and Leydig cells (d). PAS 100X.

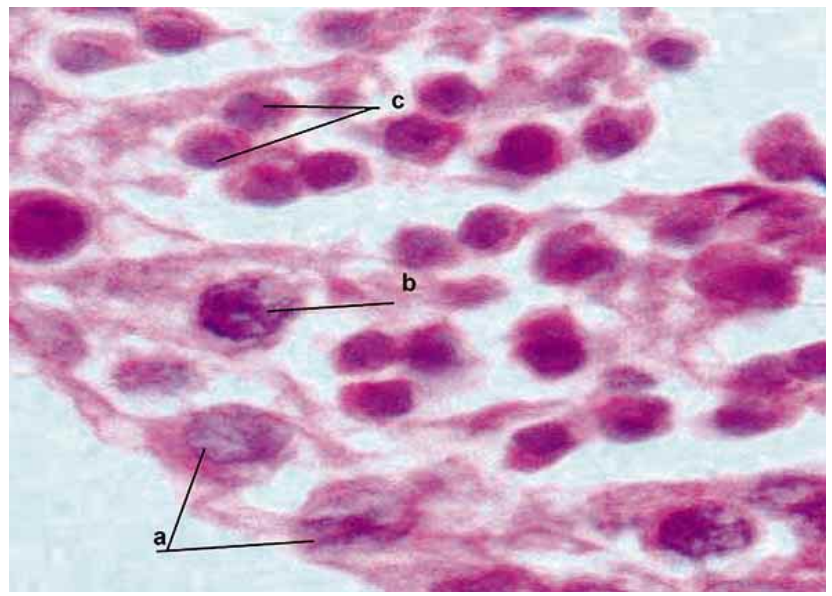

Fig. 11. Photomicrograph of testis of pubertal Gaddi goat showing enlarged view of the seminiferous tubules showing PAS reaction in the spermatogonia (a), primary spermatocytes (b), secondary spermatocytes (c). PAS 100X.

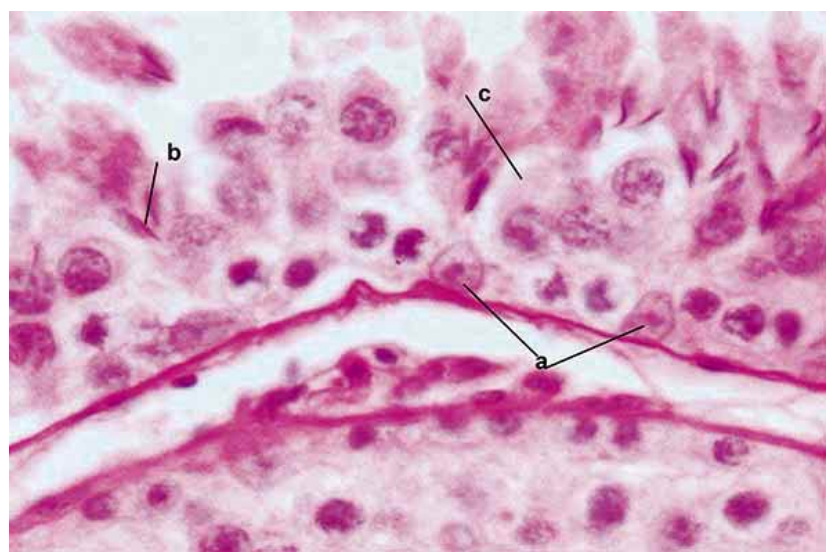

Fig. 12. Photomicrographs of testis of post-pubertal Gaddi goat showing seminiferous tubules showing spermatogenesis. Type-A spermatogonia (a), Type-B spermatogonia (b), primary spermatocytes (c), elongated spermatid (d) and Sertoli cell (e). Basement membrane was strongly positive (f). PAS 200X. 
cytoplasmic degeneration and nuclear fragmentation resulting into initiation of luminization of sex cords.

At the later stages in prepubertal animals, the testicular parenchyma was beset with well luminized seminiferous tubules. The number and size of these seminiferous tubules increased with advancement in age of the animals. The average diameter of seminiferous tubules measured $192.57 \mu \mathrm{m}$. The percent ratio between the testicular parenchyma and connective tissue was 75:25. The epithelium lining the seminiferous tubules showed spermatogenic cells in different stages of growth, proliferation and differentiation.

Spermatogonia: Close to the basement membrane lay the spermatogonia cells fixed in between the supporting cells (Sertoli cells). They were identifiable into type-A spermatogonia, intermediate type spermatogonia and typeB spermatogonia.

Type-A spermatogonia: Were large, usually elliptical or oval cells with lightly acidophilic cytoplasm lying at the periphery of tubules. The chromatin material of the nuclei was distributed uniformly throughout the nucleoplasm. Nucleoli were more than one in number (Fig. 12).

Intermediate Type Spermatogonia: These were occasionally occurring cells, generally located on the basement membrane. The cytoplasmic character of these cells was similar to Type-A spermatogonia. The chromatin material was coarse with clear unstained nucleoplasm. Generally, a single nucleolus occurred in the center of nucleus (Fig. 12).

Type-B spermatogonia: Were round in shape and slightly smaller in size as compared to the preceding two types of spermatogonia. They lay along the basement membrane among the type-A spermatogonia. The cytoplasm was lightly acidophilic as in Type-A spermatogonia. These cells had spherical nuclei, Their chromatin was usually adhered to the interior of the nuclear membrane in form of clumps. There were 2-3 nucleoli placed generally in the center of the nucleus (Fig. 12).

Primary Spermatocytes: These were large spheroidal or oval shaped cells with round or spherical nucleus with an average diameter of $6.71 \mu \mathrm{m}$. They had single centrally placed nuclei. The nuclei showed different stages of meiotic division (Fig.12).

The primary spermatocytes in leptotene phase were uniformly rounded in shape with spherical nucleus. The chromatin material in them was arranged in the form of filamentous network and filled the nucleus completely. The cytoplasm was lightly stained with eosin and formed a thin peripheral rim around the nucleus.

The primary spermatocytes in zygotene phase were marked by notched darkly stained nucleus. Their chromatin material appeared as coarse strands of homologous chromosomal pairs.

The primary spermatocytes in pachytene were large spherical cells characterized by spheroidal nucleus. The chromosomal material in them was arranged in coarse filamentous fashion leaving irregular interstices in the nucleoplasm.

The primary spermatocytes in diplotene were distinguished by their largest size. Their nuclear chromatin was loosely arranged hiding the nucleoli.

Secondary Spermatocytes: These cells were smaller than the primary spermatocytes. They were more centrally distributed as compared to the primary spermatocytes. These were rounded in shape and contained eosinophilic, granular cytoplasm. It contained spherical nucleus (diameter $5.24 \pm 0.20 \mu \mathrm{m}$ ) with a distinct nuclear membrane. The chromatin material was located centrally and arranged in fine filamentous network (Fig. 12).

Spermatids: On the basis of shape and size of cells, the three different kinds of spermatids were identified in the seminiferous tubules of Gaddi goats. First, the round spermatids were the smallest cells of spematogenic series. These had spherical nuclei, whose chromatin substance was densely granular. The nucleoli were 2-3 in number. Second, the elongating spermatids were characterized by elongated shape of their nucleus and condensed chromatin. Third, the elongated spermatids were externally condensed cells with condensed nucleus appearing more or less as spermatozoan head.

Spermatozoa: The spermatozoa were long flagellate bodies. Most of them were attached to the Sertoli cells. Some of the spermatozoa were seen lying freely in the lumina of the seminiferous tubules. The head was oval or pear shaped, stained densely with Haematoxylene. The spermatogonia, primary spermatocytes, secondary spermatocytes, spermatids and spermatozoa constituted 35 , $26,4,26$, and 8 percent, respectively of the total population of the spermatogenic cells in the seminiferous tubules.

Sertoli cells: These were tall, elongated or pyramidal shaped cells with their broad base resting on the basement membrane. The cytoplasm was finely granular, stained 
faintly with eosin. Their nuclei were spherical, oval, elongated or pear shaped, located mostly in the broader portion of the cells. It contained finely granular irregularly distributed chromatin with indistinct nucleolus. They constituted 5 percent of the total population of seminiferous tubules.

Tubuli recti: Often 2-3 tubuli contorti (sex cord) joined to form one tubuli recti in a day old kids' testis (Fig. 6). These were round tubules with narrow lumen. Their external diameter ranged from 16 to $28 \mu \mathrm{m}$, while the luminal diameter ranged from 10 to $20 \mu \mathrm{m}$. They were lined by single layer of cuboidal type cells (height 6-8 $\mu \mathrm{m}$ ). With the advancement of age, the size of tubuli recti as well as the size of its epithelium increased. These were lined with simple low columnar, cuboidal or squamous epithelium resting on the basement membrane at different stages of development (12 months- <18 months) in pre pubertal life.

Rete testes: The tubuli recti opened into a network of intercommunicating spaces, the rete testes which formed in the mediastinum testis (Fig. 12). In day old kids' testes, these were narrow, lined with low cuboidal to squamous type of epithelium resting on the basement membrane. The lumen was either empty or clogged (plug) with the detached epithelial cells from the basement membrane. The plugs appeared as crowded cells. With increase in age, the size and number of rete tubules increased. These were lined by 8 to $25 \mu \mathrm{m}$ high simple cuboidal, columnar to pseudostratified columnar epithelium with spherical to elongated nuclei in pre-pubertal animals. With the advancement of age, the basement membrane became more distinct and the size of lumen of the rete testes increased.

In pubertal animals, the tubuli contorti became much more tortuous and wide as compared to that of pre-pubertal animals. The seminiferous tubules increased in number and size. Their diameter measured on an average $202.54 \mu \mathrm{m}$ (Table I). They constituted $85 \%$ of the testicular parenchyma.

Majority of the seminiferous tubules were functional and exhibited different stages of the epithelial cycle. The relative frequency of these stages from I through VIII stages was found to be $11,12,12,5,8,18,16$ and 18 respectively.

The spermatogonia constituted 30 percent of the total population of the germinal cells observed in each cross section of the seminiferous tubules. The diameter of the nuclei of Type-A spermatogonia was $6.20 \pm 0.18 \mu \mathrm{m}$ and of Type-B spermatogonia was $4.75 \pm 0.15 \mu \mathrm{m}$. The primary spermatocytes, secondary spermatocytes, spermatids and spermatozoa constituted 20,3, 23 and 20 percent, respectively of the total population of the germinal cells in the cross-section of the seminiferous tubules. The diameter of primary and secondary spermatocytes was $6.62 \pm 0.20$ $\mu \mathrm{m}$ and $5.65 \pm 0.25 \mu \mathrm{m}$ respectively. The average size of the spermatids was $4.50 \pm 0.25 \mu \mathrm{m}$ where as the matured spermatozoa's head was $6.40 \mu \mathrm{m}$, body $4 \mu \mathrm{m}$ and tail 36 $\mu \mathrm{m}$ in length.

The Sertoli cells constituted 4 percent of the total population of the cells in the cross-section of seminiferous tubules. The diameter of the nucleus appeared to have increased.

In post-pubertal animals, the diameter of seminiferous tubules increased slightly over the preceding stage and measured $263.52 \mu \mathrm{m}$ (Table I). The Type-A spermatogonia measured $5.95 \mu \mathrm{m}$ in diameter. The type-B spermatogonia increased in number as compared to those in the previous two age groups. These were $4.65 \mu \mathrm{m}$ in diameter. The primary and secondary spermatocytes constituted 18 and $2 \%$ of the seminiferous cells in each tubular cross section.

In post-pubertal animals the morphological appearance of the seminiferous tubules differed considerably depending on the age of senility. Most seminiferous tubules in the initial stages of senility revealed different phases of nearly normal spermatogenesis as observed in the previous two groups (beyond 12 months of age).

The lumina of few seminiferous tubules contained relatively more spermatozoa than in the pubertal goats. Some tubules at this age contained relatively thinner seminiferous epithelium. Occasionally the tubules particularly the peripheral ones were entirely devoid of germinal epithelial cells lining including the spermatozoa.

Few seminiferous tubules showed vacuolated hyaline areas whereas another few tubules showed intact germinal epithelium with hyalinized mass. In certain tubules degenerative changes were observed in the spermatogenic cells. The number of seminiferous tubules without germinal epithelium was increased in the post-pubertal animals. Few seminiferous tubules showed complete fibrosis and even calcification.

The Sertoli cells formed 3 percent of the total population of the cells in a cross section of the seminiferous tubule. Cytological characters were similar to the prepubertal and pubertal group. Certain Sertoli cells showed lightly stained nuclear membrane with sparse chromatin. The nucleolus was not visible. 


\section{DISCUSSION}

The testes of Gaddi goat lay enclosed in the tunica albuginea as reported earlier in other domestic animals (Trautmann \& Fiebiger, 1957) and goats (Baishya et al., 1986a, 1986b; Islam et al., 2002; Karmore et al., 2003). Gupta reported a fibro muscular capsule of testes resembling the tunica albuginea, which measured $105 \mu \mathrm{m}$ at birth and $125 \mu \mathrm{m}$ at 6 months in old Beetal goats. Karmore et al. recorded a very thin tunica albuginea $(33.02 \pm 2.34 \mu \mathrm{m})$ in Nagpuri goats. In Gaddi goats it was $116 \mu \mathrm{m}$ at birth, 416 $\mu \mathrm{m}$ in prepubertal, $616 \mu \mathrm{m}$ in pubertal and $697 \mu \mathrm{m}$ in postpubertal stages. This indicated a progressive increase in its total thickness as also observed in buffaloes from zero to 52 weeks age (Goyal \& Dhingra, 1973). At all ages the tunica fibrosa and tunica vasculosa were clearly identified in the Gaddi goat's tunica albuginea. The two layers were 2:1, 2:1, 1.5:1 and 1.3:1 in the testes of different age groups This indicated a relative condensation of the fibrosa layer due to maturation of the collagen. The progressive growth of the capsular thickness was $4 \mathrm{X}$ of the birth time in the prepubertal animals, $6 \mathrm{X}$ in pubertal animals and $7 \mathrm{X}$ in postpubertal animals; although the rate of addition of growth was diminishing i.e. $50 \%$ more in the pubertal animals than the pre-pubertal ones, and only $11 \%$ more in the post-pubertal animals than the pubertal ones. This indicated a progressively slow rate of addition of fibrous elements to the constituents of the tunica albuginea postnatally and even condensation due to maturation of fibroblasts and fibrocytes. Gupta observed the smooth muscles in the tunica albuginia of goat testes. The same was not distinctly identified in Gaddi goat's tunica albuginea. Similar views have been reported by Islam et al. in black Bengal goats, Karmore et al. in Nagpuri goats, Chandrapal (1976) in Murrah buffalo and Trotter (1959) and Dellmann \& Wrobel (1976) in bulls. A delicate fibro reticular mediastinum testis with peripheral blood vessels occurred in the new born kids of Gaddi goats, which became more dense and rich in blood vessels and elastic fibers in the pubertal and post-pubertal ones. Similar composition and sequence of appearance of mediastinum testis has been reported in buffalo testis (Chandrapal). The septula testis were fibro cellular, rich in mesenchymal and fibroblast cells in neonates, which later condensed and was infiltrated with fine elastic fibers in the pubertal animals. Thicker and coarser collagen bundles, elastin and reticulin occurred in the post-pubertal animals. This composition of septulae testes compared well with description of Bordoloi (1979), Baishya et al. (1986a, 1986b) and Karmore et al. in goats and Chandrapal in buffaloes.

Loose fibro cellular interstitial tissue contained mesenchymal cells, fibroblasts, differentiated and undifferentiated Leydig cells in the pre-pubertal animals. The latter cells occurred either singly or in groups. Mesenchymal cells disappeared from the interstitial tissue of pubertal and post-pubertal animals. Gupta observed definitive Leydig cells in 6 months old Beetal goats as also in 6 months old human testis. Santamarina \& Reece (1957) observed Leydig cells in newborn calves which were well differentiated in 80 days-old calves. Chandrapal observed them in 9-10 months old buffalo calves.

At birth the component of testicular stroma was significantly high $(65 \%)$ as compared to the parenchyma (35\%) in the kids of Gaddi goats, which reduced considerably with the growth of the seminiferous tubules and spermatogenesis at puberty. The parenchyma and stroma ratio was reversed (60:40) at 6 months. It was 75: 25 at 12 months and 85: 15 at $>18$ months of ages. But after 5 years of age the connective tissue condensation occurred and as the seminiferous tubules started degenerating, these were further replaced by fibrous tissue. Gupta also reported an increase in the testicular parenchyma in 0-24 month old Beetal goats; the growth being maximum at 12 months and then low in 18-24 month age. Wrobell et al. (1995) observed $83 \%$ testicular parenchyma in adult German goats which matches rather closely with the present observations in mature Gaddi goats. Fossland (1954), Abdel-Raouf (1960) and Deshpande et al. (1985) observed 3-4 times increment in the testicular parenchyma of adult bovine, bull and buffalo, respectively

The parenchyma of testis comprised of non-luminated sex cord of $36.32 \mu \mathrm{m}$ diameter at birth which grew by $4 \mathrm{X}$ $(141.19 \mu \mathrm{m})$ at 6 months age. The well luminized seminiferous tubules $(192.57 \mu \mathrm{m})$ occurred in 12 months old Gaddi goats' testes which became wider $(202.54 \mu \mathrm{m})$ and more tortuous in pubertal goats; but showed degenerative changes in the post-pubertal animals as also observed in buffalo (Chandrapal). Abdel-Raouf and Gupta reported seminiferous cords in the testes of 6 months old bovine and caprine testes. The growth pattern of sex cords and seminiferous tubules from 0-24 month's age described in Beetal goats by Gupta compared well with the present studies in Gaddi goats. The sex cords of Gaddi kids (0-6 months) were filled with peripherally located small indifferent cells (4.25 $\mu \mathrm{m}$ in diameter) and centrally placed large $(8.48 \mu \mathrm{m}$ in diameter) primordial germ cells (PGC). The majority of latter cells degenerated to pave way for luminization of the sex cords while the former delineated into type-I and typeII cells. Some of the type-II cells metamorphosed in- to Sertoli cells. All other cells turned into mother (Gonia) cells in 12 months old Gaddi goat testis. Baishya et al. (1986b) reported the occurrence of large cells and small cells in Assam goat up-to 60 days age. Gupta observed the 
spermatogenic and Sertoli cells only in 12 months old kids' testes. However, before this stage the cell types were similar to the present study. The sequential fate of the large and small cells of Gaddi goats' sex cord find support from the findings of Santamarina \& Reece, Courot (1962) and Gupta in bull, lamb and Beetal bucks respectively. Clermont \& Perey (1957) and Abdel-Raouf on contrary opined the derivation of definitive germ cells from the large cells in rat and bull's testis. Observations of Goyal \& Dhingra and Chandrapal in buffalo however, favored the claim of the present study.

Well luminated seminiferous tubules lined with typical seminiferous epithelium with the process of spermatogenesis as completed by the appearance of spermatozoa was evident in the testes of 12 months old Gaddi goats. This observation was in agreement with earlier reports of Gupta in Beetal goats. However, Islam et al. reported the occurrence of spermatids in 180 days and spermatozoa in the 720 days old Black Bengal goats. Primary spermatocytes and round and oval spermatids appeared first time at 330 and 450 and 510 day of postnatal life in buffalo (Deshpande et al.). In Gaddi goats these cells appeared much earlier which might be due to species variation. It is 9 months in Jersey and 10 months in Holstein bulls (Fossland). Curtis \& Amann (1981) reported 32 weeks age in Holstein bulls.

The seminiferous epithelium comprised of spermatogonia (3 types), primary spermatocytes in different stages of meiosis, secondary spermatocytes, spermatids (2 types) and spermatozoa fixed between the Sertoli cells and arranged in many layers (3-7) as in other bovine and caprine (Santamarina \& Reece; Abdel-Rouf; Chandrapal; Bordoloi; Deshpande et al.; Gupta). In Gaddi goats the spermatogonia lay on the basement membrane and were classified as large oval A-type, small round B- type and other intermediate type as also reported in Beetal goats (Gupta). Bordoloi classified them as type A-1, type A-2 and type-B as also in buffalo by Chandrapal. Guraya \& Bilaspuri (1976), Ortavant et al. (1977), Dhingra \& Goyal (1975) further classified the type -A gonia cells into AO, A-1, A-2, and A-3 types besides the intermediate and $\mathrm{B}$ types. The latter cells were further classified into B-1, B-2 and B-3 types by Dhingra \& Goyal based on differences in their cyto-karyo-morphological characters. Such detailed classification was not possible in the Gaddi goat testes.

Primary spermatocytes in different phases of meiotic division occurred in the sections of seminiferous tubules of $>12$ months to $<60$ months age. Gupta observed them in the testes of Beetal goats of 12-24 months age. The morphological features of these cells of Gaddi goats tallied with the description given by Bordoloi and Gupta in Beetal goats, Ortavant et al. in lambs, Guraya \& Bilaspuri and Deshpande $e t$ al. in buffalo testes. Comparatively smaller than the primary spermatocytes but larger than the spermatids; the typical round shaped secondary spermatocytes were much fewer in population in the individual cross section of seminiferous tubules of late prepuberetal and pubertal animals. The much greater population of the spermatids and primary spermatocytes but much lesser population of the secondary spermatocytes at any stage in any tubular cross section; indicated the fast speed of the IInd meiotic division which it undergoes to yield the spermatids. Their population particularly receded in the post-pubertal animals' testes. This confirms the findings of Chandrapal who reported its 5.5, 4.0, and $2.5 \%$ population in prepubertal, pubertal and post-pubertal buffalo testes.

Three types i.e. rounded, elongating and elongated spermatids were identified in the testes of Gaddi goats aged $>12$ months. Similar classification of spermatids have been made in Beetal goats (Gupta) while Trautmann \& Fiebiger reported the spermatids to be smaller than the primary and secondary spermatocytes and without nucleolus. Rao et al. (1970), also reported them to be round than elongated and finally rod shaped.

Spermatozoa, the flagellate cells comprising of head, neck, body and tail mostly attached to the Sertoli cells and many lying freely in the lumen as seen in the Gaddi goat have also been reported by Gupta in Beetal goats, Chandrapal in buffalo, Trautmann \& Fiebiger and Dellmann \& Wrobel described head, neck, middle piece, principal piece and end piece of the spermatozoa in domestic animals.

Elongated or pyramidal shaped Sertoli cells with their bases resting on the basement membrane have been described in the Beetal goats (Gupta) aged 12 months or more, similar to those in Gaddi goats. However, Chandrapal described these cells to be spherical or triangular in shape with indistinct boundaries in buffalo. Their population among the seminiferous tubular cells revolved around $8 \%$ in late prepubertal, $4 \%$ in pubertal and 3\% in the old age (>60 months) Gaddi goats. Chandrapal found them to be $2-3 \%$ in prepubertal, $6 \%$ in pubertal and $4 \%$ in post-pubertal buffalo bulls.

Intra-tubular population of different spermatogenic cells varied at different reproductive stages in Gaddi goats. In pre-pubertal goats $35 \%, 26 \%, 4 \%, 26 \%$ and $9 \%$ population were recorded for spermatogonia, primary spermatocytes, secondary spermatocytes, spermatids and spermatozoa, respectively. These were $34 \%, 20 \%, 3 \%, 23 \%$ and $20 \%$ in pubertal goats. The population of primary and secondary spermatocytes was $18 \%$ and $2 \%$ respectively, in post- 
pubertal goats. The data thus revealed the fastest rate of spermatogenesis in the pubertal animals. Further that the overall number (turnover) of the spermatogonia remained unchanged in the pre-pubertal and pubertal goats. The process of spermatogenesis was slow in the post-pubertal animals. The above observation could not be compared due to non- availability of literature in this context. In the well luminated seminiferous tubules of late prepubertal $(>12$ month) and pubertal group of animals various germinal cells were arranged in varying number of layers.

The tubuli recti were formed by union of 2-3 tubuli contorti near the mediastinum testis. The diameter $(16-28 \mu \mathrm{m})$ and the height of the lining epithelium of the tubuli recti grew with age. It varied between simple low cuboidal to low columnar type as also described by Trautmann \& Fiebiger in other domestic animals. Similar sequential observations on epithelial organization have been reported in the tubuli recti of pre-pubertal, pubertal and post-pubertal buffalo by Chandrapal. The low lining epithelium of tubuli recti support the description of Dellmann \& Wrobel. The cuboidal epithelium of the tubuli changed to cylindrical type as in buffalo bull's (Dhingra, 1980) and goat testes (Kakade \& Singh, 1989).

The rete testes were the narrow intercommunicating spaces in the mediastinum testis of the early prepubertal kid's testis. With the advancing age and strengthening of the basement membrane it assumed tubular character which was lined by simple cuboidal to squamous epithelium. In later pre-pubertal and pubertal animals it was also lined by simple cuboidal and sometimes by pseudostratified columnar epithelium. Their lumina contained epithelial plugs which were more common in pubertal and post pubertal buck testes. Orsi et al. (1984) identified mediastinal part of rete testis in goats, the former yielded by union of seminiferous tubules while the latter were the large straight inter connecting canals as observed in the present study. Goyal \& Williams (1987) observed three segments of rete testis in American goats i.e. septal, mediastinal and extra-testicular. In all these cases, however the lining epithelium remained simple squamous type. Kakade \& Singh (1990) described intra-testicular (mediastinal and septal) and extra testicular rete both lined by simple cuboidal epithelium.

ARChANA, P.; KATIYAR, R. S.; SHARMA, D. N.; FAROOQUI, M. M. \& PRAKASH, A. Desarrollo postnatal del testículo en la cabra Gaddi (Capra hircus). Int. J. Morphol., 32(1):166-176, 2014.

RESUMEN: Se realizó un estudio en 30 testículos de cabras Gaddi machos divididos en 3 grupos: prepúberes ( 0 días a 18 meses), púberes (<18 meses y $>5$ años) y post-púberes ( $>5$ años). El estudio reveló que los testículos al nacimiento estaban cubiertos por una túnica albugínea fibroserosa con una capa fibrosa externa y otra capa vascular interna con fibras musculares lisas. En los animales prepúberes hasta los pospúberes, la túnica albugínea mostró un crecimiento continuo de espesor. El septo testicular derivado de la túnica albugínea, divide el parénquima en lóbulos convergentes en el mediastino testicular. En los espacios intertubulares de los testículos de los recién nacidos, se observaron escasas células interticiales diferenciadas e indiferenciadas, sin embargo, se registró un aumento importante en los animales púberes las cuales fueron reemplazadas por fibroblastos después de la pubertad. El parénquima en los testículos de los animales recién nacidos estaba compuesto por cordones sexuales continuos. Estos se convierten en túbulos luminados después de los 6 meses de edad, evidenciando túbulos contorneados y rectos que conducen al mediastino testicular. En animales de 0 días de edad, los cordones sexuales presentaban pequeñas células no diferenciadas y situadas periféricamente a lo largo de la membrana basal y grandes células germinales primordiales céntricas. A los seis meses de edad, este último comenzó a mostrar signos de degeneración. La espermatogénesis se inició en los túbulos seminíferos desde los 12 a 18 meses de edad. En los animales púberes se identificaron en los túbulos seminíferos todas las etapas de las células de espermatogénesis y células sustentaculares. La población de células gonia fue del 35\% y de espermatocitos primarios más secundarios $30 \%$. En los animales pospúberes las células gonia se redujeron a $<30 \%$ y espermatocitos primarios más secundarios a $<20 \%$. Muchos túbulos seminíferos presentaron degeneración. La relación parénquima/estroma fue 35:65 al nacer, luego de 30:60 a los 6 meses, de 25:75 a los 12 meses, de 15:85 en animales prepúberes y 20:80 en la pubertad. El aumento del estroma en la última fase fue asociado con el reemplazo de los túbulos seminíferos por elementos fibrosos.

PALABRAS CLAVE: Testículo; Histología; Desarrollo postnatal; Cabra.

\section{REFERENCES}

Abdel-Rouf, M. The postnatal development of the reproductive organs in the bull with special reference to puberty (including growth of hypophysis and adrenal). Acta Endocrinol. Suppl. (Copenh.), 49(Suppl. 49):1-109, 1960.

Baishya, G.; Ahmed, S. \& Bhattacharaya, M. Studies on testicular capsule, mediastinum testis and connective tissue pattern of male Gonads in Assam Goat (Capra hircus) during early postnatal life (0-90 days). Indian Vet. Med. J., 10(1):29-36, 1986a.
Baishya, G.; Ahmed, S. \& Bhattacharya, M. A correlative study on biometry and histomorphometry of male gonad and thyroid gland (0-90 days) in Assam goat (Capra hircus). Indian Vet. J., 63(11):928-32, 1986b.

Bordoloi, C. C. Seasonal variations on the cytomorphological and cytochemical architecture of the testis in sexually mature male goats (Capra hircus). Ph.D. Thesis, Hissar, Haryana Agricultural University, 1979. 
Chandrapal. Gross histological and histochemical studies on the male genital system of buffalo (Bubalus bubalis). Ph.D. Thesis, Agra, Agra University, 1976.

Clermont, Y. \& Perey, B. Quantitative study of the cell population of the seminiferous tubules in immature rats. Am. J. Anat., 100(2):241-67, 1957.

Courot, H. Développement du testicule chez l'agneau. Etablissement de la spermatogénèse. Ann. Biol. Anim. Bioch. Biophys., 2(1):25-41, 1962.

Curtis, S. K. \& Amann, R. P. Testicular development and establishment of spermatogenesis in Holstein bulls. J. Anim. Sci., 53(6):1645-57, 1981.

Dellmann, H. D. \& Wrobel, K.H. Male reproductive system. In: Dellman, H. D. \& Brown, E. H. (Ed.). Text book of Veterinary Histology. Philadelphia, Lea and Febiger, 1976. pp.306-11.

Deshpande, B.; Lalita, V. \& Janakiraman, K. Histological changes in male gonads from birth to sexual maturity in buffaloes. Indian J. Anim. Reprod., 6:1-4, 1985.

Dhingra, L. D. Histological and certain histochemical studies on the excurrent duct system of goat testis in different seasons of the year. Haryana Agric. Univ. Res. J.. 10(3):433-41, 1980.

Dhingra, L. D. \& Goyal, H. O. A study on the different types of spermatogonia in buffalo (Bubalus bubalis). Acta Anat. (Basel), 93(2):219-27, 1975.

Fossland, R. G. Histological development of the postnatal bovine testis. J. Dairy Sci., 37:669, 1954.

Goyal, H. O. \& Dhingra, L. D. A study on the postnatal histology of the testis in buffalo (Bubalus bubalis) from birth to one year. Acta Anat. (Basel), 84:237-50, 1973.

Goyal, H. O. \& Williams, C. S. The rete testes of goat, a morphological study. Acta Anat. (Basel), 130(2):151-7, 1987.

Gupta, A.N. Correlative Anatomy of the testes, epididymis \& accessory sex glands in goat. Ph.D Thesis, Hisar, Haryana Agricultural University, 1989.

Guraya, S. S. \& Bilaspuri, G. S. Spermatogenic cells of the buffalo (Bubalus bubalis) testis. Indian J. Anim. Sci., 46(8):388-95, 1976.

Islam, M. N.; Hossain, M. I. \& Quasem, M. A. Postnatal development of testis, epididymis and ductus deferens in Black bengal goats. Bangladesh Vet., 19:129-38, 2002.

Kakade, K. \& Singh, U. B. Histological and histo-chemical studies on the terminal segment and tubuli recti in the testis of the domestic goat (Capra hircus). Mysore J. Agric. Sci., 23:3748, 1989.
Kakade, K. \& Singh, U. B. Histological and histo-chemical studies on the rete testis of the domestic goat (Capra hircus). Mysore J. Agric. Sci., 25(3):379-82, 1990.

Karmore, S. K.; Bhamburkar, V. R.; Dalvi, S. S.; Banubakode, S. B. \& Nandeshwar, N. C. Histomorphology of testis of goat (Capra hircus). Indian J. Anim. Sci., 73(2):187-9, 2003.

Orsi, A. M.; Mombrum De Carvalho, I.; Moreira, J. E.; Valente, M. M. \& Guazzelli Filho, J. Morphology of the rete testis of the domestic goat (Capra hircus, L.). Anat. Histol. Embryol., 13(1):42-9, 1984.

Ortavant, R.; Courot, M. \& Hochereau, M. T. Spermatogenesis and morphology of the spermatozoan. In: Cole, H. H. \& Cupps, P. T. (Eds.). Reproduction in Domestic Animals. New York, Academic Press, 1977.

Rao, H. M. N.; Mouly, K. N. C. \& Rao, K. T. Cytological studies of the testis in the Indian water buffaloes (Bos bubalus). Mysore J. Agric. Sci., 4:378-84, 1970.

Santamarina, E. \& Reece, R. P. Normal development of germinal epithelium and seminiferous tubules in the bull. Am. J. Vet. Res., 18(67):261-78, 1957.

Trautmann, A. \& Fiebiger, J. Fundamentals of histology of domestic animals. Ithaca, Comstock Publishing Associates, 1957. pp.269-72.

Trotter, D. M. Histological observations of the genitalia of the immature, the castrated mature bovine male. Am. J. Vet. Res., 20:213-22, 1959.

Wrobel, K. H.; Reichold, J. \& Schimmel, M. Quantitative morphology of the ovine seminiferous epithelium. Ann. Anat., 177(1):19-32, 1995.

\author{
Correspondence to: \\ Dr. Archana Pathak \\ Associate Professor \\ Dept. of Anatomy \\ College of Veterinary Science and Animal Husbandry \\ DUVASU- Mathura \\ INDIA
}

Email: Pathak_arcvik@yahoo.com

Received: 17-06-2013

Accepted: 17-11-2013 